\title{
Effects of Stakeholder Pressure, Corporate Governance, and Profitability on Carbon Emission Disclosures
}

\author{
Siti Choiriah ${ }^{1 *}$, Ria $^{2}$ \\ ${ }^{1}$ Universitas Mercubuana, Jakarta Indonesia \\ ${ }^{2}$ Universitas Nasional, Jakarta, Indonesia
}

DOI: $10.36348 /$ sjef.2020.v04i06.003

| Received: 30.05 .2020 | Accepted: 07.06.2020 | Published: 12.06.2020

*Corresponding author: Siti Choiriah

Email: choiriahsc@mercubuana.ac.id

\section{Abstract}

This study aims to examine the effect of Stakeholder Pressure, Corporate Governance, and Profitability on Carbon Emission Disclosure. The population in this study are manufacturing and mining companies for the period 2013-2017 which are listed on the Indonesia Stock Exchange. The sample in this study was 41 companies that met the criteria. A purposive sampling technique was used in this study for sampling. To test the hypothesis using multiple linear regression. In line with the theory of legitimacy, stakeholder theory, and agency theory the results of this study found that Corporate Governance and Profitability have a positive effect on Carbon Emission Disclosure.

Keywords: Greenhouse gases, Disclosure of Carbon Emissions, Continuity, Profitability, Corporate Governance.

Copyright @ 2020: This is an open-access article distributed under the terms of the Creative Commons Attribution license which permits unrestricted use, distribution, and reproduction in any medium for non-commercial use (NonCommercial, or CC-BY-NC) provided the original author and source are credited.

\section{INTRODUCTION}

From 2015 - 2018 the increase in global temperature was triggered by Greenhouse Gases (GHGs) which trap geothermal heat and has exceeded the record. Several countries in the world made a commitment as stipulated in the Kyoto Protocol, namely the Kyoto Protocol to the United Nations Framework Convention on Climate Change (UNFCCC) in 1997 which began in force since 2005. Indonesia has set commitments in Perpres No. 61/2011 on the National Mitigation Action Plan (RAN-GRK) in an effort to reduce greenhouse gas emissions by $26 \%$ in 2020 and $41 \%$ in 2030. According to scientists, this year's El Nino event is causing an increase in extreme weather which is exacerbated by climate change as well making 2019 the hottest year in Indonesian history. In 2019 , China will become one of the biggest contributors to carbon emissions, which is $25 \%$.

The Indonesian government still pays little attention to the implementation of carbon accounting, this is due to low human resources and the applicable law is still not firm about this problem. One potential reason for the lack of impact of carbon disclosure to date is the quality and comparability of the information provided [1]. Economic performance will be a relevant factor in determining whether environmental activities are a priority [2]. Double [3] revealed that reducing carbon emissions increases the company's financial return. Good and efficient corporate operations are one of the objectives of governance according to Choiriah $[4,28]$.

Companies with greater financial resources and returns tend to pursue environmental strategies and reporting. When company public information is improved, information disclosure can be very useful for predicting future income and for reducing the cost of capital of a company [2]. Meanwhile, according to Nengzih [5] Companies with good governance, management control systems and planning will have an impact on the company's survival. Lovell [6] says that voluntary initiatives pressure companies to publish GHG reporting. Companies are under pressure to report, assess and reduce carbon emissions which are the main factors of GHG from various stakeholders, which include shareholders, employees, consumers, creditors, government, and also the community [1] because according to Pratiwi [7] stakeholders can influence decisions about carbon performance in companies. Stakeholder pressure has an impact on disclosure of carbon emissions, although not too much because this disclosure is voluntary so the disclosure is incomplete. This causes the disclosure of each company to be different and causes stakeholders to find difficulties in comparing company performance. Jaggi1 research results [8] also argue that the strength of 
stakeholders has a significant influence on the managerial behavior of companies in disclosing carbon emissions in Italy.

Various factors can encourage companies to disclose carbon emissions information. Companies with better environmental performance are encouraged to disclose more carbon emission information because these companies want to increase value and be different from lower ranked companies. This is consistent with signaling theory, disclosure regulation theory, where companies can increase their value through financial reporting. The corporate governance mechanism can ensure that management conducts business accordingly. This gives a guarantee that the company is well managed and in accordance with the rules and needs of the community. Corporate governance mechanisms can be used to encourage companies to be environmentally responsible, including reporting company actions. Choi et al. [9] states that the quality of corporate governance is one of the influential factors that influence the disclosure of carbon emissions. This study aims to determine the relationship between stakeholders, corporate governance with the proxy of the audit committee and profitability on disclosure of carbon emissions in manufacturing and mining companies in Indonesia. The difference between this research and previous research is stakeholder pressure measurement, which in the previous research uses proxies of employees, NGOs, countries, creditors, media, etc. However in this study, the board of directors is the top management in running the company. Disclosure of social and environmental responsibility based on GRI guidelines. Factors that are thought to influence the disclosure of social responsibility are internal and external to the company, namely creditors, board of directors, markets, and company performance. It is hoped that this research can be a reference for further research on carbon emission disclosures, and provide input for developing carbon emission disclosures, and can provide information both to readers, investors and potential investors, and even the government.

\section{LITERATURE REVIEW Stakeholder Theory}

Most of them are normative organizational theories [10] which refer to the simple and basic idea that a business has stakeholders that is, there are groups and individuals who have an interest in the success or failure of a business [11]. Stakeholder theory can be applied to all types of social systems in general and organizational systems in particular [12]. Legitimacy theory and stakeholder theory have provided theoretical motivation for social disclosure. Research that theorizes and interprets environmental disclosures and stakeholder perspectives is rare. Social disclosure is used strategically to regulate relations with stakeholders by influencing external demands originating from many different constituencies [13]. Agency theory (Agency Theory) explains that the separation between ownership and management of a company is always followed by the emergence of costs due to the asynchronous interests between owners and managers [14]. In such a situation, it is not uncommon for differences in interests between principals and agents that represent their principal interests [15]. Companies have contract costs as well as low or high supervision costs for the benefit of management, including improving reputation in the community by incurring significant costs related to social responsibility [16].

\section{Legitimacy Theory}

A social contract that is often used to review how businesses discuss with the public. This is related to community expectations about how to work to ensure they survive in the future. The social contract does not have to be a written agreement, but what we understand must be from the community. Legitimacy theory is used to explain the process by which social contracts are accepted. This theory states that organizations can only make there a community where they agree that they operate in a value system created with community property [5]. The clear values and norms in social contracts have changed over time. In the past, only reliable in terms of economic performance. This has changed and businesses are now expected to consider various issues, including considering the environmental and social aspects of their activities.

Stakeholders have the ability to control the company in carrying out its activities including disclosure. Guenther et al. [17] and Liesen et al. [1] say that stakeholder pressure has a positive effect on carbon disclosure. Stakeholder pressure proxy by the board of directors is due to the large responsibility of the board of directors to control the activities of companies that are under a lot of pressure in achieving Goals Company. They are basically the ones who run the company. The Directors also take part in the financial reporting process, including deciding what to include in financial reporting. The board of directors or Board of Directors (BOD) tends to encourage companies to disclose more information in their financial reporting because BOD members have a long-term orientation towards corporate social responsibility [2, 18]. Thus BOD will encourage companies to disclose more information about the company's environmental responsibility, which includes carbon emissions information. Several studies have found conflicting results that with larger BOD sizes, fewer carbon emissions information disclosed [19]; Lorenzo et al., [2]. Yunus [20] states that companies with board members the larger one has the influence to deal with issues related to carbon emissions to avoid the potential damage to the company's reputation and there by maintaining legitimacy, as more boards of directors will increase monitoring capacity.

$\mathrm{H}_{1}$ : The board of directors has a positive effect on carbon emission disclosure 
Corporate governance mechanisms can be used to encourage companies to be environmentally responsible, including reporting company actions [21]. The audit committee as a proxy of Corporate Governance is responsible for overseeing and monitoring the financial reporting process, and for checking whether the financial statements are prepared in accordance with relevant regulations. The function of the audit committee is to support the transparency and accountability of information provided by the company. They supervise, supervise, and monitor the financial reporting process. The number of members of the audit committee will affect the effectiveness of the committee in overseeing the financial reporting process, including information on carbon emissions disclosed therein. Chariri [22] and Kiswanto et al. [23] prove that the audit committee has a positive influence on carbon emission disclosure.

$\mathrm{H}_{2}$ : The Audit Committee has a positive effect on carbon emission disclosure

Profitability reflects the company's financial performance. Companies with poor financial performance will give an extra focus on achieving financial goals and improving their performance, and thus causing their ability to prevent and report carbon emissions to be limited [2]. This study uses the ROA ratio to calculate profitability. Research conducted by Lorenzo [2] and Halimah [24] supports the link between profitability and disclosure of carbon emissions.

H4: Profitability has a positive effect on carbon emission disclosure.

\section{RESEARCH METHODOLOGY}

The population in this study are manufacturing and mining companies listed on the Indonesia Stock Exchange (IDX) for the 2013-2017 period. In sample selection using purposive sampling. This type of research is quantitative with the relationship of dependent and independent variables. Calculation of carbon emission disclosure items by adopting GRI (Global Reporting Initiative)

In categorizing carbon emission disclosure data, the researcher adopts the analysis content which is compiled based on the factors identified in the Global Reporting Initiative, the total items disclosed against the total number of whole items.

For the first proxy, the board of directors is used as a measurement of stakeholder pressure. For corporate governance variables measured by the number of members of the audit committee [21]. In this study the company's profitability is measured by the ratio of return on assets (ROA) as in research conducted by Akbas [25].

Hypothesis testing uses statistical analysis using multiple regression analysis to determine the relationship between the independent variable and the dependent variable, as follows:

$$
\begin{aligned}
\mathrm{CED}=\alpha+\beta 1 \mathrm{SP}+ & \beta 2 \mathrm{CG}+\beta 3 \mathrm{PROFIT}+\mathrm{e} \\
\mathrm{CED} & : \text { Carbon emission disclosure } \\
\alpha & : \text { Konstanta } \\
\mathrm{e} & : \text { Error atau pengaruh luar } \\
\beta 1-\beta 4 & : \text { Koefisien } \\
\mathrm{SP} & : \text { Stakeholder Pressure (Dewan Direksi) } \\
\mathrm{CG} & : \text { Corporate Governance (Komite audit) } \\
\text { Profit } & : \text { Profitabilitas }
\end{aligned}
$$

\section{RESULTS AND DISCUSSION}

With the determined criteria, 139 companies were listed on the Indonesia Stock Exchange during the study period, and 32 companies met the criteria. So that the amount of data used in this study in the 5 year period of the company amounted to 160 data. However, due to very significant nominal differences in each of the existing data, 160 of the initial data could not pass the statistical test and the classical assumption test, so the researcher conducted an outlier that left a decent amount of 110 data

Table-1: Descriptive Statistics Test Results

\begin{tabular}{|l|l|l|l|l|l|}
\hline \multicolumn{7}{|c|}{ Descriptive Statistics } \\
\hline & $\mathbf{N}$ & Minimum & Maximum & Mean & Std. Deviation \\
\hline CED & 110 & .02 & .99 & .3358 & .20847 \\
\hline SP & 110 & 3.00 & 11.00 & 5.8636 & 1.86458 \\
\hline PROFIT & 110 & .00 & .43 & .1437 & .11047 \\
\hline CG & 110 & 3.00 & 5.00 & 3.2000 & .48463 \\
\hline Valid N (listwise) & 110 & \multicolumn{7}{|c|}{ Source: Outpus SPSS } & & \\
\hline
\end{tabular}

Source: Outpus SPSS

Descriptive statistics describe the description or description of a data that is seen from the average value (average), standard deviation, maximum and minimum [26]. From Table 1 it can be seen the number of samples $(\mathrm{N})$ there are 110 data that fall into the category of manufacturing and mining companies. Disclosure of Carbon Emissions has the lowest (minimum) value of 0.02 at and for the largest value (maximum) of 0.99 . While the average value (average) of 0.3358 which means the value of carbon emissions disclosure in the manufacturing and mining companies for the period 2013-2017 amounted to $33.58 \%$ The standard deviation value of the variable carbon emissions disclosure of 0.20847 this is the value the 
average disclosure of carbon emissions is greater than the standard deviation which means that the data can be approved both and distributed data equally. Stakeholder Pressure (SP) proxied by the Board of directors has the lowest value (minimum) of 3 and the largest value is 11. While the mean value is 5.86 with a standard deviation of 1.864. This shows that the average SP value is greater than the standard deviation which means the data is approved either because the variation between the minimum and maximum values is low. Profitability has the lowest value (minimum) of $0.0 \%$ for the largest value of 0.43 . The average (average) profitability variable is 0.143 with a standard deviation of the profitability variable of 0.11 . This shows the average value of the profitability variable is greater than the value of the standard deviation which means the standard error of the variable profitability is low.

This research is a number of tests to ascertain the feasibility of the data used. And all classic assumption tests state that the data is normally distributed and meets the classical assumption test requirements.

Table-2

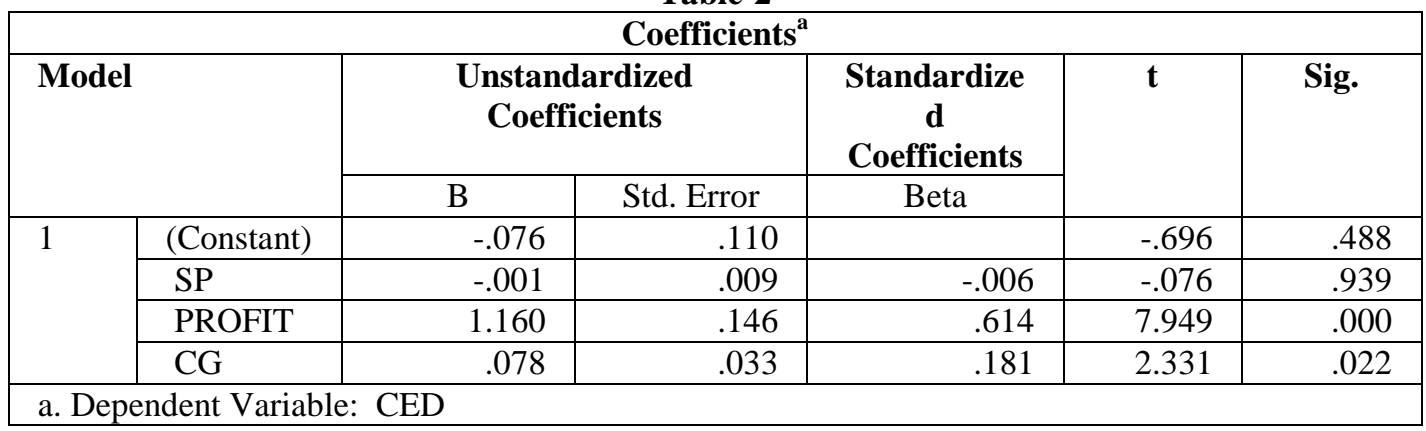

Source: Outpus SPSS

Based on the results of the hypothesis test (see table 2), it is known that the Stakeholder Presure with the board of directors proxy with a t-value of -0.76 and a significance value of $0.939>(0.05)$ means that Stakeholder Pressure has no effect on Carbon Disclosure and the first hypothesis is rejected. According to Krishnamurti \& Velayuthan [8] states that more carbon disclosure if the company has an environmental / sustainability committee at the board level than the board of directors. The establishment of a joint audit committee and risk management committee will decrease significantly because disclosure is a source of risk because this type of disclosure can create risk and is valuable information for competitors. This study is not in line with the research of Guenther et al. [17] and Lee [3] which states that all stakeholders influence the disclosure of carbon emissions.

Based on the results of the second hypothesis testing the audit committee as a proxy of Corporate Governance (CG) has a significant positive value that is with a t value of 7.949 and a significance value of 0.000 means that the second hypothesis is accepted. This study supports research conducted by Chariri [22] and Kiswanto et al. [23] which states that the audit committee has a positive effect on carbon emission disclosure. A qualified audit committee will better understand the impact of disclosure of information in accordance with broad stakeholder wishes. The existence of an audit committee can help disclose guaranteed information and the company's control system can run well. The more the number of audit committees, the more the company's activities to conduct carbon emission disclosures because supervision by the company becomes more effective. Through a larger number of audit committees will be increasingly able to encourage management to implement carbon emissions disclosure practices as a medium of corporate communication with stakeholders to demonstrate quality corporate governance.

The results of the profitability hypothesis test by measuring the ROA have a sig of $0.022<(0.05)$ and a t-value of 2.3331 so that profitability has a significant positive effect on carbon emission disclosure. With these results support the third hypothesis where companies with high profits will pay more attention to environmental performance. Companies that have a good level of profitability will focus on maintaining or increasing company profits and public trust by having good environmental performance, especially disclosure of carbon emissions. Whereas for companies with a low level of profitability, they tend to focus on their financial performance by finding ways to increase the company's profit so that the company does not pay too much attention to the company's environmental performance.

However, it cannot be said that companies in Indonesia, either with high or low profit levels, will always disclose carbon emissions, this is because the sustainability report in this country is still voluntary and there is no law that requires companies to disclose their carbon emissions, so companies those who have carbon emission disclosure are merely voluntary. But from the results of this study with a sample of companies that reveal carbon emissions it can be seen that ROA can affect the disclosure of carbon emissions. The results of 
this study are supported by previous studies from Hermawan [27] and Halimah [24]. But it is different from the results of Pratiwi's research [7] which states that profitability does not affect carbon emission disclosure.

Based on research that has been done with the audit committee, and profitability shows that the indicator affects the disclosure of carbon emissions. In the future, it is hoped that the government will be able to consider, formulate, stipulate, and require Carbon Emision Disclosure disclosures and reporting standards that are in accordance with Indonesian conditions, so that companies can add complete information related to carbon emission disclosures. Because the disclosure of carbon emissions is an important assessment for the sustainability of the company.

\section{ACKNOWLEDGMENT}

This study support by the Faculty of Economics and Business and Research Center of Universitas Mercu Buana Jakarta. I'm grateful for the supported from Dean, Rector Research Center team and especially the respondent in this study.

\section{REFFERENCE}

1. Liesen, A., Hoepner, A. G., Patten, D. M., \& Figge, F. (2015). Does stakeholder pressure influence corporate GHG emissions reporting? Empirical evidence from Europe. Accounting, Auditing \& Accountability Journal.

2. Dwyer, R., Lamond, D., Prado- Lorenzo, J. M., Rodríguez- Domínguez, L., Gallego- Álvarez, I., \& García- Sánchez, I. M. (2009). Factors influencing the disclosure of greenhouse gas emissions in companies world- wide. Management Decision.

3. Lee, S. H., \& Lee, S. Y. (2018). An analysis of the effects of climate change policy, stakeholder pressure, and corporate carbon management on carbon efficiency on the Korean petrochemical industry. Sustainability, 10(12), 4420.

4. Asare, T. (2009). Internal auditing in the public sector: Promoting good governance and performance improvement. International Journal on Governmental Financial Management, 9(1), 1528.

5. Nengzih. (2014). Corporate Governance, Internal Control And Voluntary Disclosures Of Environmental Accounting To Company Performance : Evidence From Hospital Industries In Indonesia, Research Journal of Finance and Accounting, 5(22): 134-145

6. Lovell, H., Bebbington, J., Larrinaga, C., \& de Aguiar, T. R. S. (2013). Putting carbon markets into practice: a case study of financial accounting in Europe. Environment and Planning $C$ : Government and Policy, 31(4), 741-757.

7. Pratiwi, D. N. (2018). Implementasi Carbon Emission Disclosure di Indonesia. Jurnal Ilmiah
Akuntansi dan Bisnis, 13(2), 101-112.

8. Jaggi, B., Allini, A., Macchioni, R., \& Zagaria, C. (2018). The factors motivating voluntary disclosure of carbon information: Evidence based on Italian listed companies. Organization \& Environment, 31(2), 178-202.

9. Choi, B. B., Lee, D., \& Psaros, J. (2013). An analysis of Australian company carbon emission disclosures. Pacific Accounting Review.

10. LeRoux, K. (2009). Managing stakeholder demands: Balancing responsiveness to clients and funding agents in nonprofit social service organizations. Administration \& Society, 41(2), 158-184.

11. Freeman, R. E., Harrison, J. S., Wicks, A. C., Parmar, B. L., \& De Colle, S. (2010). Stakeholder theory: The state of the art. Cambridge University Press.

12. Valentinov, V., Roth, S., \& Will, M. G. (2019). Stakeholder theory: a Luhmannian perspective. Administration \& Society, 51(5), 826849.

13. Van der Laan, S. (2009). The role of theory in explaining motivation for corporate social disclosures: Voluntary disclosures vs 'solicited'disclosures. Australasian Accounting, Business and Finance Journal, 3(4), 2.

14. Jensen, M. C., \& Meckling, W. H. (1979). Theory of the firm: Managerial behavior, agency costs, and ownership structure. In Economics social institutions (pp. 163-231). Springer, Dordrecht.

15. Santoso, B. (2015). Keagenan (Agency): PrinsipPrinsip Dasar, Teori, dan Problematika Hukum Keagenan. Penerbit Ghalia Indonesia. Jakarta.

16. Suaryana, A. (2011). Faktor-Faktor Yang Mempengaruhi Kebijakan Pengungkapan Tanggung Jawab Sosial Dan Lingkungan Pada Perusahaan Manufaktur Di Bursa Efek Indonesia. Jurnal Ilmiah Akuntansi dan Bisnis.

17. Guenther, E., Guenther, T., Schiemann, F., \& Weber, G. (2016). Stakeholder relevance for reporting: explanatory factors of carbon disclosure. Business \& Society, 55(3), 361-397.

18. Hillman, A. J., \& Dalziel, T. (2003). Boards of directors and firm performance: Integrating agency and resource dependence perspectives. Academy of Management review, 28(3), 383-396.

19. Manurung, D. T. H., Kusumah, R. W. R., Asikin, B., \& Suryani, I. (2017). Peran Corporate Governance dan Komite lingkungan dalam Pengungkapan Gas Rumah Kaca. In 4 th International Conference On Business, Economics and Social Science (pp. 1-41).

20. Yunus, S., Elijido-Ten, E., \& Abhayawansa, S. (2016). Determinants of carbon management strategy adoption: Evidence from Australia's top 200 publicly listed firms. Managerial Auditing Journal, 31(2), 156-179.

21. Budiharta, P., \& Kacaribu, H. E. P. B. The Influence of Board of Directors, Managerial 
Ownership, and Audit Committee on Carbon Emission Disclosure: A Study of Non-Financial Companies Listed on BEI.

22. Chariri, A., Januarti, I., \& Yuyetta, E. N. A. (2018). Audit Committee Characteristics and Carbon Emission Disclosure. In E3S Web of Conferences (Vol. 73, p. 02001). EDP Sciences.

23. Akhiroh, T., \& Kiswanto, K. (2016). The Determinant of Carbon Emission Disclosures. Accounting Analysis Journal, 5(4), 326-336.

24. Halimah, N. P., \& Yanto, H. (2018). Determinant of Carbon Emission Disclosure at Mining Companies Listed in Indonesia Stock Exchange. KnE Social Sciences, 127-141.
25. Akbaş, H. E., \& Canikli, S. (2018). Determinants of Voluntary Greenhouse Gas Emission Disclosure: An Empirical Investigation on Turkish Firms. Sustainability, 11(1), 1-24.

26. Ghozali, I. (2018). Aplikasi analisis multivariate Dengan Program IBM SPSS 25 Edisi 9, Cet. 9. Semarang: Badan Penerbit-UNDIP.

27. Amanah, L. (2018). Pengaruh Kinerja Keuangan Terhadap Nilai Perusahaan Dengan Pengungkapan Corporate Social Responsibility Sebagai Variabel Pemoderasi. Jurnal Ilmu dan Riset Akuntansi (JIRA), 7(11).

28. Choiriah, (2019b) Effectiveness of Internal Control, Good Governance, and Ethics on Budgetary Discipline, Schollar Bulletin, Vol. 5 (12) p.1-7 